\title{
Księga PamiątKowa i Jubileusz Profesora Edwarda Kolodzieja
}

1P) rofesor Edward Kołodziej jest jednym z najbardziej znanych badaczy 11 sierpnia 1940 r. w Białymstoku pod okupacją radziecką w rodzinie Stanisława i Danuty z domu Zając. Tam, w latach 1947-1950, uczęszczał do szkoły powszechnej, którą ukończył po przeprowadzce rodziny - w Warszawie. W stolicy, w maju 1958 r., zdał maturę i rozpoczą studia historyczne na Uniwersytecie Warszawskim. Pod kierunkiem prof. Żanny Kormanowej (1900-1988) ${ }^{1}$ przygotował pracę magisterską pt. Międzynarodowy ruch robotniczy $w$ polskiej prasie socjalistycznej $w$ latach 1889-1895, obronioną w 1963 roku.

Po studiach podjął pracę w Archiwum Akt Nowych (AAN) w Warszawie, w którym zatrudniony był do

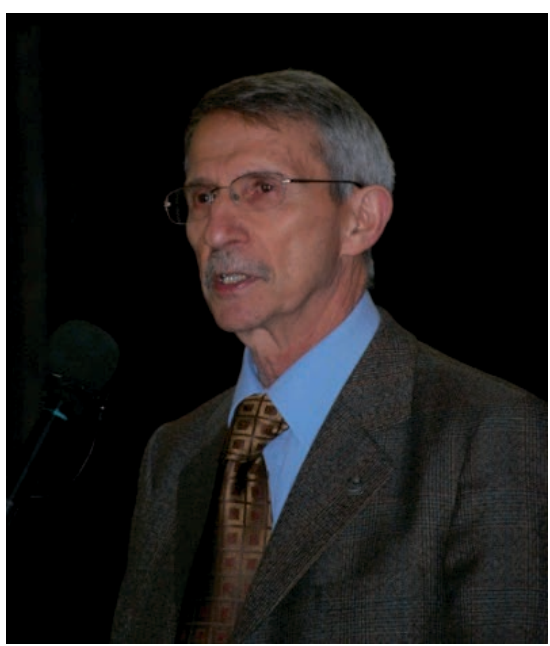

Prof. zw. dr hab. Edward Kołodziej [źródło: http://histmag.org/?id=2541 (25.012012)]

1 Zob. A. Pacholczyk, Kormanowa Żanna, [w:] Stownik historyków polskich, pod red. M. Prosińskiej-Jackl, Warszawa 1994, s. 245. Szerzej o dorobku naukowym zob. „Z Pola Walki”, nr 4, 1980. 
emerytury, a obecnie pracuje na 1/4 etatu. Tam w praktyce zdobył szlify archiwisty, które zaowocowały następnie badaniami naukowymi. W 1972 r. obronił rozprawę doktorską pt. Dziatalność Komunistycznej Partii Robotniczej Polski w ruchu zawodowym w latach 1918-19232, przygotowaną na seminarium prof. Ż. Kormanowej. Siedem lat później na podstawie książki Wychodźstwo zarobkowe z Polski 1918-1939. Studia nad polityka emigracyjna II Rzeczypospolitej $j^{3}$ uzyskał na Uniwersytecie Wrocławskim stopień doktora habilitowanego w zakresie historii najnowszej. Wówczas został w AAN docentem, konsekwentnie odmawiając przyjmowania jakichkolwiek funkcji kierowniczych i administracyjnych. Od 1985 r. jest członkiem Komitetu Badań nad Migracjami w Polskiej Akademii Nauk (Wydział I Nauk Humanistycznych i Społecznych) ${ }^{4}$. W dniu 7 grudnia 1999 r. z rąk prezydenta RP Aleksandra Kwaśniewskiego odebrał nominację na profesora nauk historycznych ${ }^{5}$.

Od 1999 r. - pracując nadal w AAN - podjął wykłady w Instytucie Historii Uniwersytetu Marii Curie-Skłodowskiej w Lublinie, na kierunku archiwistyka, a także od 2005 r. w ramach Podyplomowego Studium Archiwistyki UMCS. Tam 14 września 2005 r. wypromował jednego doktora - Władysława Horsta na podstawie rozprawy Kancelarie i archiwa Centralnego Komitetu Wykonawczego Polskiej Partii Socjalistycznej, Komitetu Centralnego Polskiej Partii Robotniczej i Komitetu Centralnego Polskiej Zjednoczonej Partii Robotniczej (1944-1990) ${ }^{6}$. Na UMCS wypromował także 56 magistrów. Był rów-

2 E. Kołodziej, Komunistyczna Partia Robotnicza Polski w ruchu zawodowym 1918-1923, Warszawa 1978, ss. 250.

3 E. Kołodziej, Wychodźstwo zarobkowe z Polski 1918-1939. Studia nad polityka emigracyjną II Rzeczypospolitej, Warszawa 1982, ss. 294. W 1983 r. książka została wyróżniona Nagrodą im. Prof. Floriana Znanieckiego, nadawaną przez Polskie Towarzystwo Socjologiczne.

4 Zob. http://nauka-polska.pl/dhtml/raporty/ludzieNauki? rtype=opis\&objectId=63 002\&lang=pl (data dostępu: 18.01.2012).

5 Zob. http://forumakad.pl/archiwum/2000/01/artykuly/02-kronika.htm (data dostępu: 18.01.2012).

6 „Przedłożona praca jest zarysem dziejów kancelarii i archiwów Centralnego Komitetu Wykonawczego Polskiej Partii Socjalistycznej, Komitetu Centralnego Polskiej Partii Robotniczej i Komitetu Centralnego Polskiej Zjednoczonej Partii Robotniczej (1944-1990). Opisuje warunki w jakich powstawała i funkcjonowała biurowość i systemy kancelaryjne "partii władzy» oraz omawia archiwa partyjne i ich zadania w zakresie przejmowania, opracowania, udostępniania i popularyzacji zasobu. problemy kancelarii i archiwów "partii władzy» wynikały w znacznym stopniu ze specyfiki związanej z ich miejscem i rolą w życiu społeczno-politycznym kraju, co znajdowało odbicie nie 
nież 13 marca 2003 r. recenzentem rozprawy doktorskiej Krzysztofa Czubary pt. Dziatalność Powiatowego Urzędu Bezpieczeństwa Publicznego w Zamościu $w$ latach 1944-19477, powstałej pod kierunkiem prof. Tadeusza Radzika ${ }^{8}$. W 2006 r. został profesorem zwyczajnym UMCS.

W 2000 r. otrzymał nagrodę Rady Porozumiewawczej Badań nad Polonią. Od 2001 r. jest redaktorem nowej edycji „Tek Archiwalnych. Seria nowa” (stara edycja była wydawana przez NDAP w latach 1953-1992). W 1979 r. został odznaczony Srebrnym Krzyżem Zasługi, a w 2011 r. Krzyżem Kawalerskim Orderu Odrodzenia Polski.

Dorobek naukowy Jubilata za lata 1966-2009 składa się z 26 książek, ponad 120 artykułów oraz ponad 60 recenzji, a także z licznych biogramów i prac popularnonaukowych. Łącznie ukazało się ponad dwieście publikacji’

tylko w odniesieniu do stosowanych systemów kancelaryjnych czy w funkcjonowaniu archiwów, ale i w dążeniach niektórych przedstawicieli aparatu partyjnego do tworzenia własnych normatywów w tym zakresie. Mimo to działalność podstawowa kancelarii i archiwów budowa[na] była głównie w powiązaniu i w oparciu o przepisy obowiązujące w państwowej służbie archiwalnej. Na podstawie zachowanej dokumentacji wykazano, że mimo powszechnego stosowania w ówczesnej praktyce kancelaryjnej systemu dziennikowego już w 1946 r. proponowano wprowadzenie w registraturach CKW PPS, a w 1948 roku w registraturach KC PZPR systemu bezdziennikowego. Od 1955 r. system taki obowiązywał w kancelarii Wydziału Historii Partii, w 1958 r. wprowadzono go także w Wydziale Agitacji i Propagandy KC PZPR, a od 1959 r. formalnie obowiązywał we wszystkich kancelariach KC PZPR. Opinie te zmieniają dotychczasowe ustalenia badawcze, o registraturach Komitetu Centralnego PZPR. Wiele uwagi poświęcono niedociągnięciom i mankamentom towarzyszącym działalności kancelarii i archiwów. Istotnym efektem pracy jest ustalenie, że te słabości i nieprawidłowości w funkcjonowaniu są jedną z ważniejszych przyczyn braków w udokumentowaniu wielu ważnych stron funkcjonowania badanych partii co ma wpływ na wartość informacyjną zachowanych źródeł”. Zob. http://nauka-polska.pl/dhtml/raporty/praceBadawcze?rtype=opis\&lan$\mathrm{g}=$ pl\&objectId=54862 (data dostępu: 10.01.2012).

7 Zob. http://nauka-polska.pl/dhtml/raporty/praceBadawcze?rtype=opis\&lang=pl\& objectId=26178 (data dostępu: 10.01.2012).

${ }^{8}$ Zob. D. Matelski, Profesor Tadeusz Radzik (1953-2009), [w:] Problemy historii wojskowości w kraju i na obczyźnie po wrześniu 1939 roku. Studia historyczne i politologiczne. Tom dedykowany pamięci nestora historyków polskich profesora Józefa Jasnowskiego (1906-2009), pod red. L. Nowaka, M. Szczerbińskiego i G. Wieczorka, Gorzów Wielkopolski 2010, s. 621-626.

9 A. Laskowska, Bibliografia prac prof. dr. hab. Edwarda Kotodzieja [za lata 1966-2009 (nr 1-217)], [w:] Archiwistyka oraz problemy historii Polski, Polonii i dyplomacji XX wieku. Ksiega jubileuszowa ofiarowana profesorowi Edwardowi Kotodziejowi w 70. rocznice urodzin, pod red. J. Łosowskiego, Lublin 2011, s. 21-39. Zob. także 
Ważne miejsce - ze względu na pracę w Archiwum Akt Nowych w Warszawie - stanowią publikacje zwarte, dotyczące jego zasobu archiwalnego ${ }^{10}$, dziejów Archiwum Akt Nowych ${ }^{11}$, inwentarzy archiwalnych po zespołach przechowywanych w Archiwum Akt Nowych ${ }^{12}$, edycji źródeł do dziejów dy-

publikacje z lat 2010-2011: E. Kołodziej, Zjazdy i konferencje konsulów polskich w Rumunii w okresie międzywojennym. Protokoty i referaty, Lublin 2010, ss. 359 (współautorzy: Henryk Chałupczak i Małgorzata Willaume); tenże, Źródta do dziejów Mazowsza w latach II Rzeczypospolitej, [w:] Dzieje Mazowsza 1918-1939, t. 4, pod red. J. Szczepańskiego, Pułtusk 2010, s. 7-17; tenże, Życie gospodarcze, [w:] Dzieje Mazowsza 1918-1939, t. 6, pod red. J. Szczepańskiego, Pułtusk 2010, s. 271-387; tenże, Korespondencja Józefa Stojanowskiego, kierownika Archiwum Akt Nowych, z Witoldem Suchodolskim, dyrektorem Archiwów Państwowych, z lat 1944-1945 w sprawie ratowania akt archiwów warszawskich, „Teki Archiwalne. Seria nowa”, Warszawa 2009 (2010), t. 10 (32), s. 271-286; tenże, Jerzy Michat Stoch (1922-2008), „Teki Archiwalne. Seria nowa", Warszawa 2009 (2010), t. 10 (32), s. 431-432; tenże, Zjazdy konsulów polskich $w$ ZSRR. Protokoty i referaty 1927-1934, Lublin 2011, ss. 467 (współautorzy: Mariusz Mazur i Tadeusz Radzik).

${ }^{10}$ E. Kołodziej, Polonia zagraniczna. Informator o materiatach źródtowych do $1939 r$. przechowywanych w Archiwum Akt Nowych, Warszawa1981, ss. 57; tenże, Emigracja $z$ ziem polskich i Polonia 1865-1939. Informator o źródtach przechowywanych $w$ centralnych archiwach państwowych w Polsce, Kraków 1988, ss. 236; tenże, Emigracja z ziem polskich i Polonia 1939-1965. Informator o źródtach przechowywanych $w$ centralnych archiwach państwowych $w$ Polsce, Warszawa 1996, ss. 156; tenże, Ameryka Eacińska, Hiszpania i Portugalia w źródtach Archiwum Akt Nowych do roku 1945, Warszawa 1996, ss. 224 (współautor: Rafał Mrowiec); tenże, Emigracja z ziem polskich i Polonia 1939-1965. Informator o źródtach przechowywanych $w$ centralnych archiwach pañstwowych $w$ Polsce, Warszawa 1996, ss. 155; tenże, Emigracja z ziem polskich i Polonia 1831-1939. Informator o źródtach przechowywanych $w$ terenowych archiwach państwowych $w$ Polsce, Warszawa 1997, ss. 185; tenże, Informator o zasobie Archiwum Akt Nowych. Stan na 31 marzec 2005, Warszawa 2007, ss. 698.

${ }^{11}$ E. Kołodziej, Zarys dziejów Archiwum Akt Nowych w latach 1919-2008, Warszawa 2008, ss. 280; tenże, Archiwum Akt Nowych w Warszawie, Warszawa 2009, ss. 49; tenże, Zmiany w zasobie Archiwum Akt Nowych, „Dzieje Najnowsze”, nr 3, 1994, s. $87-97$.

12 E. Kołodziej, Inwentarz akt konsulów polskich w Niemczech 1918-1939, Opole 1983, ss. 119; tenże, Inwentarz akt Ambasady RP w Berlinie z lat [1919] 1920-1939 (do roku 1934 poselstwa), Warszawa 1990, ss. 421; tenże, Inwentarz akt Ministerstwa Spraw Zagranicznych $w$ Warszawie $z$ lat [1915-1917] 1918-1939, Warszawa 2000, ss. 482; tenże, Inwentarz akt Ambasady Rzeczypospolitej Polskiej w Bukareszcie z lat 1919-1940 (do roku 1938 poselstwa), Warszawa 2002, ss. 95; tenże, Inwentarz akt Antoniego Pająka (premiera Rządu Rzeczypospolitej Polskiej na Uchodźstwie) i jego rodziny, Warszawa 2008, ss. 64 (współautor: Bartosz Nowożyński). 
plomacji polskiej i wychodźstwa polskiego ${ }^{13}$ oraz monografii dotyczących Polonii ${ }^{14}$, związków zawodowych i ruchu robotniczego ${ }^{15}$ czy polskich Ziem Zachodnich i Północnych ${ }^{16}$.

Ponadto zwróćmy jeszcze uwagę na artykuły odnoszące się do polityki Rzeczypospolitej wobec wychodźstwa polskiego, dziejów Polonii i badań nad jej losami. Zaliczamy do nich teksty o Polonii niemieckiej ${ }^{17}$, Polonii w Ame-

13 E. Kołodziej, Zjazdy i konferencje konsulów polskich w Niemczech. Protokoty i sprawozdania 1920-1939, Lublin 1999, ss. 375 (współautor: Henryk Chałupczak); tenże, Zjazdy i konferencje konsulów polskich w Niemczech. Referaty 1928-1938, Lublin 2001, ss. 526 (współautor: Henryk Chałupczak); tenże, Zjazdy i konferencje konsulów polskich w USA i Kanadzie. Protokoty i referaty 1920-1938, Lublin 2004, ss. 344 (współautor: Tadeusz Radzik); tenże, Zjazdy i konferencje konsulów polskich we Francji. Protokoty i referaty 1931-1938, Lublin 2009, ss. 486 (współautor: Henryk Chałupczak); tenże, Zjazdy konsulów polskich w ZSRR. Protokoty i referaty 1927-1934, Lublin 2011, ss. 467 (współautorzy: Mariusz Mazur i Tadeusz Radzik).

${ }^{14}$ E. Kołodziej, Wychodźstwo zarobkowe z Polski 1918-1939. Studia nad polityka emigracyjna II Rzeczypospolitej, Warszawa 1982, ss. 294; tenże, Dzieje Polonii w zarysie 1918-1939, Warszawa 1991, ss. 286.

15 E. Kołodziej, Kronika Zwiazku Zawodowego Pracowników Leśnych i Przemystu Drzewnego 1893-1973, Warszawa 1974, ss. 142; tenże, Organizacje związkowe pracowników poczt, telegrafów i telefonów w Polsce 1918-1939, Warszawa 1979, ss. 248; tenże, Polski ruch robotniczy. Informator o materiatach źródtowych z lat 1900-1950 przechowywanych w Archiwum Akt Nowych, Warszawa 1985, ss. 72 (współautor: Artur Pałasiewicz).

16 E. Kołodziej, Migracje ludności na Ziemiach Zachodnich i Pótnocnych w latach 1945-1950. Informator o źródtach przechowywanych w terenowych archiwach państwowych, Warszawa 1998, ss. 188.

17 E. Kołodziej, Prześladowania ludności polskiej w Niemczech (maj-sierpień 1939 r.) - materiaty źródtowe, „Teki Archiwalne”, 1972, nr 13, s. 53-83; tenże, Raporty, referaty i sprawozdania o potożeniu robotników rolnych $w$ Niemczech (1920-1939), „Teki Archiwalne”, 1973, nr 14, s. 93-150; tenże, Ruch zawodowy wśród polskich robotników rolnych w Rzeszy 1918-1939, „Kwartalnik Historii Ruchu Zawodowego”, 1973, nr 3, s. 3-25; tenże, Źródta do dziejów Polaków na Warmii, Powiślu i Mazurach oraz IV Dzielnicy Zwiąku Polaków w Niemczech w okresie międzywojennym przechowywane w Archiwum Akt Nowych, „Komunikaty Mazursko-Warmińskie”, nr 1 (159), 1983, s. 99-107; tenże, Konsulat Rzeczypospolitej Polskiej w Lipsku w latach 1923-1939. Organizacja i dziatalność, [w:] Na szachownicy dziejów i międzynarodowej polityki. Księga dedykowana profesorowi Zbigniewowi Brzezińskiemu, pod red. J. Farysia, H. Kocója i M. Szczerbińskiego, Gorzów Wielkopolski 2006, s. 255-269. 
ryce Północnej, Środkowej i Południowej ${ }^{18}$, Polonii francuskiej ${ }^{19}$, Polonii rosyjskiej i radzieckiej ${ }^{20}$, emigracji zarobkowej z Polski ${ }^{21}$, polityki II Rzeczypo-

18 E. Kołodziej, Emigration from II Polish Republic to America on Background of Employment Seeking, [w:] Emigration Process from Poland: Number and Structure. International Symposium, Kraków, November 9-11, 1981, „Zeszyty Naukowe Uniwersytetu Jagiellońskiego", z. 8, 1984, s. 165-184; tenże, Protokoty konferencji konsulów polskich z USA i Kanady z roku 1920, „Teki Archiwalne. Seria nowa”, t. 1 (23), 1996, s. 81-101; tenże, Polacy $w$ Ameryce Eacińskiej wobec kwestii odrodzenia niepodlegtego państwa polskiego, [w:] Polonia w walce o niepodlegtość i granice Rzeczypospolitej 1914-1921, Pułtusk 1999, s. 170-194; tenże, Polonia w Ameryce Eacinskiej wobec walki o niepodlegtość Polski i jej granice w latach 1914-1921, [w:] Z dziejów Polski i emigracji (1939-1989). Księga dedykowana bytemu prezydentowi Rzeczypospolitej Polskiej Ryszardowi Kaczorowskiemu, pod red. Marek Szczerbiński i Tadeusz Wolsza, Gorzów Wielkopolski 2003, s. 205-215; ten$\dot{z}$, Source for the history of American Polonia in the collections of Archiwum Akt Nowych in Warsaw, „Polish-American Studies”, vol. 40, nr 1, 2003, s. 99-109; tenże, Źródta do dziejów Polonii amerykańskiej w zasobie Archiwum Akt Nowych w Warszawie, „Przegląd Polonijny”, z. 4 (114), 2004, s. 177-181; tenże, Źródta do dziejów Polonii amerykańskiej w zasobie Archiwum Akt Nowych w Warszawie, [w:] Losy Polaków pośród swoich i obcych. Annales Universitatis Mariae Curie-Skłodowska, sekcja F, vol. 60, 2005, s. 127-136; tenże, Polska stużba dyplomatyczna i konsularna a Polonia $w$ USA i Kanadzie w latach 1918-1939, [w:] Polonijna panorama. Szkice poświęcone pamięci Bolestawa Wierzbiańskiego, Opole 2008, s. 127-139.

19 E. Kołodziej, Źródta do dziejów emigracji i Polonii francuskiej w polskich archiwach państwowych, "Teki Archiwalne. Seria nowa”, t. 2 (24), 1997, s. 237-248; tenże, Sources pour l' historie de l' imigration et de la Polonia de France dans les archives nationals polonaises, [w:] La protection des polonaise en France, problèmes d'integration et d'assimilation, Lille 1999, s. 93-108.

20 E. Kołodziej, Źródta do dziejów Polaków w Cesarstwie Rosyjskim, Związku Radzieckim i Mandżurii z XIX i XX wieku przechowywane w polskich archiwach państwowych, „Niepodległość i Pamięć”, nr 2, 1998, s. 169-178; tenże, Organizacje polskie w Mandżurii w latach 1917-1920, [w:] Polonia w walce o niepodlegtość i granice Rzeczypospolitej 1914-1921, Pułtusk 1999, s. 195-205.

21 E. Kołodziej, Emigracja zarobkowa z Polski w latach 1918-1939. Liczebność i struktura, [w:] Liczba i rozmieszczenie Polaków w świecie, cz. I, Wrocław 1981, s. 63-92; tenże, Emigracja zarobkowa z Polski w latach 1918-1925 w'swietle polityki emigracyjnej, [w:] Studia z dziejów polskiego ruchu robotniczego, t. 2, Warszawa 1983, s. 81-104; tenże, Polonia w XIX i XX wieku, „Biuletyn Informacyjny Domu Polonii w Pułtusku”, nr 4, 1989, s. 3-11; tenże, Emigracja zarobkowa z ziem polskich w XIX i XX wieku, [w:] Polska emigracja, Warszawa 1990, s. 15-22; tenże, Emigracja z ziem polskich i Polonia 1871-1939. Liczebność i rozmieszczenie, „Przeszłość Demograficzna Polski”, cz. 1, Warszawa 1990, s. 13-51; tenże, Emigracja zarobkowa z Polski, [w:] Nowa encyklopedia powszechna PWN, t. 2, Warszawa 1994, s. 242; tenże, Emigracja z ziem polskich od końca XIX wieku do czasów wspótczesnych i tworzenie się skupisk polonijnych, [w:] Emigracja z ziem polskich w XX wieku. Drogi awansu emigrantów, Pułtusk 1998, s. 11-24. 
spolitej wobec wychodźstwa polskiego ${ }^{22}$, harcerstwa polskiego na obczyźnie ${ }^{23}$, depatriacji ${ }^{24}$ i repatriacji Polaków z ZSRR po II wojnie światowej ${ }^{25}$, poloników w archiwach zagranicznych ${ }^{26}$. Recenzował także publikacje dotyczą-

22 E. Kołodziej, Materiaty do dziejów ruchu robotniczego w aktach polskich placówek dyplomatycznych i konsularnych 1918-1939/1941, „Z Pola Walki”, nr 4, 1974, s. 350-357; tenże, Ostatnie posiedzenie Międzyministerialnej Komisji Emigracyjnej z 25 lutego 1939 r., „Teki Archiwalne”, nr 16, 1977, s. 181-235 (współautor: Janina Zakrzewska); tenże, Raporty emigracyjne konsulów polskich w Brukseli i Antwerpii, „Teki Archiwalne”, nr 19, 1982, s. 125-176 (współautor: Janina Zakrzewska); tenże, Organizacja i kancelarie polskich placówek dyplomatycznych i konsularnych w latach 1939-1945, „Archeion”, t. 75, 1983, s. 151-177; tenże, Rola polskich placówek dyplomatycznych i konsularnych w latach 1939-1945, [w:] Wtadze RP na obczyźnie podczas II wojny światowej, Londyn 1994, s. 774-820; tenże, II Rzeczpospolita wobec potrzeb kulturalnych Polonii, [w:] Kultura skupisk polonijnych, Warszawa 1994, s. 57-79; tenże, Wybuch wojny i polska stużba zagraniczna 1939-1940, [w:] Materiaty do dziejów polskiego uchodźstwa niepodlegtościowego 1939-1990, Londyn 1996, s. 81-92; tenże, Organizacja centrali i placówek MSZ w latach 1918-1939, [w:] Z dziejów polskiej stużby dyplomatycznej. Księga upamiętniająca życie i dzieto Jana Nowaka Jeziorańskiego, pod red. J. Farysia i M. Szczerbiński, Gorzów Wielkopolski 2005, s. 171-182.

23 E. Kołodziej, Źródta do dziejów harcerstwa na obczyźnie przechowywane w Archiwum Akt Nowych oraz w innych archiwach panstwowych, [w:] Dzieje harcerstwa na obczyźnie w latach 1912-1992, pod red. M. Szczerbińskiego, Gorzów Wielkopolski 1992, s. 21-28; tenże, Harcerstwo polskie we Francji, Belgii i Holandii w latach międzywojennych o jego miejsce w systemie oświaty polonijnej, [w:] Miscellanea oświaty polonijnej, Bydgoszcz 1999, s. 31-44; tenże, Harcerstwo polskie w Belgii w latach międzywojennych, [w:] Organizacje polonijne. Dzieje - wspótczesność-perspektywy, pod red. M. Szczerbińskiego, Gorzów Wielkopolski 2001, s. 75-83.

24 Depatriacja to przesiedlenia ludności polskiej z ziem II RP, które w 1944 r. zostały odstąpione ZSRR. Zaś repatriacja to przesiedlenia ludności polskiej z pozostałych obszarów ZSRR. Zob. szerzej: J. Pruszyński (1941-2008), Dziedzictwo kultury Polski. Jego straty i ochrona prawna, t. 1-2, Kraków 2001.

25 E. Kołodziej, Polityka Rzadu RP $w$ Warszawie wobec repatriacji i reemigracji obywateli polskich z ZSRR w latach 1944-1948, „Komunikaty Mazursko-Warmińskie”, nr 2-3 (204-205), 1994, s. 317-332; tenże, Sprawozdanie Gtównego Petnomocnika Rzadu RP do spraw Ewakuacji Ludności Polskiej z SRR $w$ Wilnie z przebiegu zbiorowej repatriacji w latach 1945-1946, „Teki Archiwalne. Seria nowa”, t. 2 (24), 1997, s. 167-194; tenże, Repatriacja ludności polskiej z Ukrainy w latach 1944-1946 w świetle dokumentów przechowywanych w Archiwum Akt Nowych, „Teki Archiwalne. Seria nowa”, t. 3 (24), 1998, s. 113-140.

26 E. Kołodziej, Archiwalia w Instytucie Polskim i Muzeum im. gen. Wtadystawa Sikorskiego w Londynie, „Archeion”, t. 95, 1995, s. 103-113; tenże, Polonika z lat 1918-1938 w Archiwum Republiki w Wiedniu, „Teki Archiwalne. Seria nowa”, t. 1 (23), 1996, s. 177-185; tenże, Archiwalia w zbiorach polskich ośrodków emigracyjnych, [w:] Pamiętnik III Powszechnego Zjazdu Archiwistów Polskich. Toruń 2-4 września 1997 r., t. 1, Radom 


\section{KRONIKA}

ce zagadnień archiwalnych: archiwów austriackich ${ }^{27}$, niemieckich ${ }^{28}$, szwaj-

1997, s. 39-48; tenże, Polonika w Bundesarchiv, „Archeion”, t. 99, 1998, s. 123-137; tenże, Archiwa polonijne $w$ zbiorach polskich ośrodków emigracyjnych $i$ w archiwach $w$ Polsce, [w:] Diaspora polska w procesach globalizacji. Stan i perspektywy badań, Kraków 2006, s. 316-338.

27 E. Kołodziej (rec.), Mitteilungen des Östrereichischen Staatsarchivs, t. 19 (1966), „Archeion”, t. 49, 1968, s. 220-221; tenże, Mitteilungen des Östrereichischen Staatsarchivs, t. 20 (1967), Archeion”, t. 54, 1970, s. 280-281; tenże, Mitteilungen des Östrereichischen Staatsarchivs, t. 21 (1968), „Archeion”, t. 55, 1971, s. 244; tenże, Mitteilungen des Östrereichischen Staatsarchivs, t. 23 (1970), „Archeion”, t. 59, 1973, s. 243-245; tenże, Mitteilungen des Östrereichischen Staatsarchivs, t. 24 (1971), „Archeion”, t. 60, 1974, s. 308-310; tenże, Mitteilungen des Östrereichischen Staatsarchivs, t. 25 (1972), „Archeion”, t. 61, 1974, s. 267-268; tenże, Mitteilungen des Östrereichischen Staatsarchivs, t. 26 (1973), „Archeion”, t. 62, 1975, s. 209-210; tenże, Mitteilungen des Östrereichischen Staatsarchivs, t. 27 (1974), „Archeion”, t. 64, 1976, s. 209-211; tenże, Mitteilungen des Östrereichischen Staatsarchivs, t. 28 (1975), „Archeion”, t. 67, 1979, s. 271-275; tenże, Mitteilungen des Östrereichischen Staatsarchivs, t. 29 (1976), „Archeion”, t. 68, 1979, s. 272-273; tenże, Mitteilungen des Östrereichischen Staatsarchivs, t. 30 (1977), „Archeion”, t. 69, 1979, s. 370-371; tenże, Mitteilungen des Östrereichischen Staatsarchivs, t. 31 (1978), „Archeion”, t. 71, 1981, s. 273-274; tenże, Mitteilungen des Östrereichischen Staatsarchivs, t. 32 (1979), „Archeion”, t. 72, 1981, s. 362-364; tenże, Mitteilungen des Östrereichischen Staatsarchivs, t. 33 (1980), „Archeion”, t. 75, 1983, s. 318-321; tenże, Mitteilungen des Oberöstrereichischen Landesarchivs, t. 13 (1981), „Archeion”, t. 77, 1984, s. 242-244; tenże, Mitteilungen des Östrereichischen Staatsarchivs, t. 35 (1982), „Archeion”, t. 79, 1985, s. 274-277; tenże, Mitteilungen des Östrereichischen Staatsarchivs, t. 39 (1986), „Archeion”, t. 87, 1990, s. 247-251; tenże, Mitteilungen des Steiermärkischen Landesarchivs, t. 35-36, „Archeion”, t. 87, 1990, s. 251-253; tenże, Mitteilungen des Östrereichischen Staatsarchivs, t. 40 (1987), „Archeion”, t. 92, 1993, s. 162-164; tenże, Mitteilungen des Oberöstrereichischen Landesarchivs, t. 16 (1990), „Archeion”, t. 93, 1994, s. 274-276; tenże, Mitteilungen des Östrereichischen Staatsarchivs, t. 41 (1990), „Archeion”, t. 93, 1994, s. 276-278; tenże, Mitteilungen des Östrereichischen Staatsarchivs, t. 42-43 (1992-1993), „Archeion”, t. 95, 1995, s. 162-167; tenże, Archiv der Republik. Eine Bestandsübersicht, Wien 1996, „Archeion”, t. 96, 1996, s. 188-189; tenże, Pobyt w Östrereichisches Staatsarchiv-Archiv der Republik w Wiedniu, „Archeion”, t. 97, 1997, s. 412-425.

28 E. Kołodziej (rec.), Das Stadtarchiv Weimar und seine Bestände, „Archeion”, t. 51, 1969, s. 241-242; tenże, Archivmitteilungen, nr 1 (1967), nr 6 (1968), „Archeion”, t. 51, 1969, s. 277-278; tenże, Archivalische Zeitschrift, t. 62 (1966), „Archeion”, t. 56, 1971, s. 314-315; tenże, Archivalische Zeitschrift, t. 66 (1970), Archeion, t. 58, 1973, s. 163-165; tenże, Archivalische Zeitschrift, t. 67 (1971), „Archeion”, t. 59, 1973, s. 225-228; tenże, Übersicht über die Quellen zur Geschichte Latainamerikas in Archiven der DDR, „Archeion”, t. 61, 1974, s. 296-297; tenże, „Archivalische Zeitschrift”, t. 68 (1972), „Archeion”, t. 60, 1974, s. 298-301; tenże, „Archivalische Zeitschrift”, t. 69 (1973), „Archeion”, t. 61, 1974, s. 254-255; tenże, H. Lötzke, Deutsches Zebtralarchiv 1946-1971, Potsdam 1970, „Archeion”, t. 64, 1976, s. 234-236; tenże, „Archivalische 
carskich $^{29}$, indyjskich ${ }^{30}$, amerykańskich ${ }^{31}$, brytyjskich ${ }^{32}$, a także zamieszczał biogramy archiwistów ${ }^{33}$ i spuścizn archiwalnych ${ }^{34}$.

W 2009 r. Zakład Archiwistyki Instytutu Historii Uniwersytetu Marii Curie-Skłodowskiej, kierowany przez prof. n. dr. hab. Janusza Łosowskiego, podjął się przygotowania jubileuszowej księgi dla uczczenia 70. urodzin oraz

Zeitschrift”, t. 70 (1974), „Archeion”, t. 64, 1976, s. 198-199; tenże, „Archivalische Zeitschrift”, t. 71 (1975), „Archeion”, t. 65, 1977, s. 272-273; tenże, Polonika w Bundesarchiv, „Archeion”, t. 99, 1998, s. 123-137.

${ }^{29}$ E. Kołodziej (rec.), „Mitteilungen der Vereinigung Schweizerischer Archivare”, nr 21 (1970), „Archeion”, t. 54, 1971, s. 331-332; tenże, Schweizerische Archivführer. Guide des Archives Suisses, Zürich 1971, „Archeion”, t. 64, 1976, s. 241-242.

${ }^{30}$ E. Kołodziej (rec.), „The Indian Archives”, Vol. 23, No. 1-2 (1974), „Archeion”, t. 68, 1979, s. 268-269; tenże, „The Indian Archives”, Vol. 24-25, No. 1-2 (1975-1976), "Archeion”, t. 69, 1979, s. 353-357; tenże, „The Indian Archives”, Vol. 28, No. 1-2 (1979), „Archeion”, t. 75, 1983, s. 309-312; tenże, „The Indian Archives”, Vol. 29, No. 2 (1980), Vol. 30, No. 1 (1981), „Archeion”, t. 77, 1984, s. 135-239; tenże, „The Indian Archives”, Vol. 41, No. 1 (1992), „Archeion”, t. 96, 1996, s. 258-259.

${ }^{31}$ E. Kołodziej, Mikrofilmy archiwaliów z USA w Bibliotece Instytutu Badań Ameryki Pótnocnej w Berlinie Zachodnim, „Archeion”, t. 91, 1993, s. 235-238; E. Kołodziej (rec.), „The American Archivist”, Vol. 52, No. 2 i 4 (1989), „Archeion”, t. 91, 1993, s. 247-253; tenże, J. Cisek (opr.), Instytut Józefa Pitsudskiego w Ameryce i jego zbiory, Warszawa 1997, „Archeion”, t. 100, 1999, s. 265-267.

32 E. Kołodziej (rec.), „Archives. The Journal of the British Records Association”, Vol. 20, No. 91, 1992, „Archeion”, t. 95, 1995, s. 149-151; tenże, "Archives. The Journal of the British Records Association”, Vol. 22, No. 93, 1995, „Archeion”, t. 97, 1995, s. 268-270; tenże, „Archives. The Journal of the British Records Association”, Vol. 21, No. 92, 1994, „Archeion”, t. 96, 1996, s. 249-251.

${ }^{33}$ E. Kołodziej, Bogdan Kroll, „Teki Archiwalne. Seria nowa”, t. 4 (26), 2000, s. 267-268; tenże, Barbara Teresa Woźniakowska, „Teki Archiwalne. Seria nowa”, t. 4 (26), 2000, s. 268-269; tenże, Bogdan Kroll, [w:] Stownik biograficzny archiwistów polskich, t. 2, pod red. B. Woszczyńskiego, Warszawa 2002, s. 96-97; tenże, Andrzej Marek Piber, [w:] Stownik biograficzny archiwistów polskich, t. II, s. 136-137; tenże, Barbara Teresa Woźniakowska, [w:] Stownik biograficzny archiwistów polskich, t. II, s. 194; tenże, Mścistaw Kiejstut Jerzy Wróblewski, „Teki Archiwalne. Seria nowa”, t. 8 (30, 2004, s. 323-324.

${ }^{34}$ E. Kołodziej, Wspomnienia i spuścizny prywatne w Archiwum Akt Nowych, „Życie Warszawy", nr 158 z 4 lipca 1973 (współautor: Jerzy Stoch); tenże, Nieznane dokumenty o Karolu Szymanowskim, „Życie Warszawy”, nr 61 z 27-28 marca 1982 (cz. I), nr 67 z 3-4 kwietnia 1982 (cz. II); tenże, Akta profesora Janusza Kazimierza Zawodnego z lat 1942-2001 w Archiwum Akt Nowych, „Studia Archiwalne”, t. 1, 2004, s. 125-132. 
45-lecia pracy zawodowej prof. zw. dr. hab. Edwarda Kołodzieja. Wsparcia inicjatywnie udzieliła Naczelna Dyrekcja Archiwów Państwowych w Warszawie. Zaproszono do udziału w księdze przedstawicieli licznych ośrodków naukowych w Polsce. Drukiem ukazała się w 2011 r. pt. Archiwistyka oraz problemy historii Polski, Polonii i dyplomacji XX wieku. Ksiega jubileuszowa ofiarowana profesorowi Edwardowi Kotodziejowi w 70. rocznice urodzin, pod redakcją Janusza Łosowskiego (Lublin 2011, ss. 663, il.). Zamieszczone studia - oprócz wstępu pióra Redaktora prezentującego sylwetkę Jubilata oraz Jego bibliografii prac za lata 1966-2009 (zestawionej przez Agnieszkę Laskowską, zob. przypis 9) - podzielono na sześć merytorycznych części, zatytułowanych: I. Archiwiści, archiwa oraz ich użytkownicy ${ }^{35}$, II. Akta, archiwalia oraz ich zawartość ${ }^{36}$, III. Społeczeństwo polskie, ruchy polityczne, postawy indywidualne ${ }^{37}$,

35 Irena Mamczak-Gadkowska (Poznań), Problematyka archiwalna na powszechnych zjazdach historyków polskich w okresie międzywojennym (s. 47-64); Dariusz Matelski (Poznań-Łódź), Restytucja dóbr kultury w uktadach Polski z sasiadami w XX wieku (s. 65-97); Alicja Kulecka (Warszawa), Archiwa francuskie - przedmiot fascynacji archiwistów polskich (s. 99-117); Anna Laszuk (Warszawa), Użytkownicy wspóttwórcami informacji o zasobie archiwalnym (s. 119-133); Marek Konstankiewicz (Lublin), Udziat w stanowieniu aktów normatywnych jako forma dziatania administracji archiwalnej $w$ zakresie ksztattowania narastającego zasobu archiwalnego (s. 135-145); Halina Robótka (Toruń), System Informacji Archiwalnej ZoSIA. Bilans otwarcia (s. 147-160); Kazimierz Kozłowski (Szczecin), Ksztattowanie i rozwój szczecińskiego Archiwum Państwowego w polskich strukturach państwowych (do 1975 roku) (s. 161-174); Władysław Stępniak (Toruń-Warszawa), Wyzwania etyczne w zawodzie archiwisty (s. 175-186); Marcin Kula (Warszawa), Fantazyjne życzenia dla archiwisty (s. 187-195).

36 Władysław Horst (Warszawa), Akta Komendy Gtównej Policji Państwowej (1918-1939) w zasobie Archiwum Akt Nowych w Warszawie (s. 199-225); Bartosz Nowożycki (Warszawa), Spuścizna Antoniego Pajaka. Problem opracowania i zawartości (s. 227-240); Stefan Ciara (Warszawa), Adam Skatkowski (1877-1951) i jego notatnik archiwalny (s. 241-256); Tomasz Czarnota (Lublin), Problematyka archiwów i archiwaliów emigracyjnych oraz poloników w "Kulturze” i „Zeszytach Historycznych” (s. 257-306).

37 Teresa Kulak (Wrocław-Opole), „Emigracja wewnętrzna” Elizy z Branickich Zygmuntowej Krasinskiej (1820-1876) (s. 309-322); Wiesław Śladkowski (Lublin), Wtościanie klucza cycowskiego przed i po uwtaszczeniu (s. 323-329); Albin Koprukowniak (Lublin), Obraz statystyczny miasta prywatnego Czemierniki w 1860 roku (s. 331-340); Tadeusz Krawczak (Warszawa), Rządy chetmskiego biskupa greckokatolickiego Jana Mikotaja Kalińskiego (1863-1866) (s. 341-357); Edward Długajczyk (Katowice), Na ziemi opolskiej po I powstaniu śląskim 1919 roku (s. 359-384); Janusz Szczepański (Lublin), Separatystyczne tendencje Wielkopolski i Pomorza [Gdańskiego] w okresie najazdu bolszewickiego w 1920 roku (s. 385-396); Wojciech Wrzesiński (Wrocław), Wokót charakteru i postaw narodowych Polaków w latach II wojny światowej na tamach „Biuletynu Informacyjnego” 
IV. Historia Polonii i jej epizody ${ }^{38}$, V. Polska dyplomacja i jej pracownicy ${ }^{39}$, VI. Problemy prawa oraz integracji europejskiej ${ }^{40}$.

Uroczystość wręczenia Księgi Jubileuszowej prof. Kołodziejowi miała miejsce 21 grudnia i rozpoczęła się o godzinie $12 \mathrm{w}$ nowym budynku Wydziału Humanistycznego UMCS w sali obrad Rady Wydziału. Otwarcia uroczystości dokonał prof. Krzysztof Skupieński, który przywitał Jubilata oraz wszystkich zgromadzonych gości. Wśród licznego grona zaproszonych gości (około 60 osób) byli: naczelny dyrektor Archiwów Państwowych w Warszawie prof. n. dr hab. Władysław Stępniak ${ }^{41}$, dyrektor Archiwum Akt Nowych w Warszawie dr Tadeusz Krawczak, dyrektor Archiwum Państwowego w Lublinie dr Piotr Dymmel, dziekan Wydziału Humanistycznego UMCS prof. Henryk Gmiterek, dyrektor Instytutu Historii UMCS prof. Robert Litwiński i kierownik Zakładu Archiwistyki UMCS prof. Janusz Łosowski. Liczną reprezentację stanowili również pracownicy Archiwum Akt Nowych oraz pracownicy naukowi poszczególnych zakładów Instytutu Historii UMCS.

(s. 397-420); Anna Łosowska (Lublin), Dlaczego nie wydano ksieggi pamiatkowej 5-lecia UMCS? Nieznany epizod z dziejów Uczelni w pierwszym okresie jej istnienia (s. 421-452); Zbigniew Zaporowski (Lublin), Powstanie i struktury organizacyjne Niezależnego Samorzadnego Związku Zawodowego „Solidarność” na Uniwersytecie Marii Curie-Sktodowskiej (wrzesień-grudzień 1980) (s. 453-485).

38 Jan Lewandowski (Lublin), Polacy i Polonia $w$ krajach battyckich $w$ dobie porozbiorowej (s. 489-500); Krzysztof Smolna (Warszawa), Towarzystwo Przyjaciót Ameryki Łacińskiej w Londynie (s. 501-508); Anna Nowakowska-Wierzchoś (Warszawa), Zwiazek Kobiet Polskich imienia Marii Konopnickiej we Francji (s. 509-529); Robert Litwiński (Lublin), Zamorski contra Żóttaszek. $Z$ dziejów postaw Polaków na wychodźstwie po 1 września 1939 roku (s. 531-547).

${ }^{39}$ Henryk Chałupczak (Lublin), Konsulaty RP w Niemczech, Francji i Rumunii w okresie międzywojennym. Wybrane zagadnienia (s. 551-575); Wanda Krystyna Roman (Toruń), Kazimierz Trębicki [1896-1981] - ostatni konsul II Rzeczypospolitej w Genewie (s. 577-598); Adam Grzegorz Dąbrowski (Warszawa), Przekazanie kopii dokumentów znalezionych $w$ kwietniu 1927 r. w budynku ambasady radzieckiej $w$ Pekinie. Przyczynek do dziejów polsko-japońskiej wspótpracy wywiadowczej w okresie dwudziestolecia międzywojennego (s. 599-614).

40 Małgorzata Polkowska (Warszawa), Rozwój prawa lotniczego. Od konferencji w Paryżu w roku 1910 do konferencji w Chicago w roku 1944 (s. 617-649); Małgorzata Willaume (Lublin), Integracja - funkcja matematyczna czy spoteczna? (s. 651-658).

${ }^{41}$ Zob.http://www.archiwa.gov.pl/pl/naczelna-dyrekcja-archiwow-pastwowych.html (25.01.2012). 
Następnie odczytano nadesłane listy od osób, które nie mogły przyjechać na uroczystość, a chciały w czasie jej zabrać głos. Kolejnym punktem uroczystości były przemówienia. Pierwszy głos zabrał prorektor UMCS prof. Ryszard Szczygieł, który odczytał list z gratulacjami Rektora UMCS prof. Andrzeja Dąbrowskiego, a także w swoim imieniu pogratulował Jubilatowi. Dziekan Wydziału Humanistycznego prof. H. Gmiterek dziękował za pracę w murach Uczelni oraz życzył dalszych sukcesów naukowych. Z kolei dr hab. W. Stępniak przedstawił liczne zasługi i dokonania prof. E. Kołodzieja dla archiwistyki oraz jej propagowania. Prof. Kołodziej został w nim przedstawiony za wzór archiwisty praktyka, jak i teoretyka. Przemówienie kończyły słowa zachęty do dalszej pracy naukowej. Ostatnim planowanym przemówieniem w pierwszej części uroczystości było wystąpienie dyrektora Instytutu Historii UMCS prof. R. Litwińskiego, w czasie którego, oprócz gratulacji, został wręczony prof. Kołodziejowi najnowszy tom (31) „Res Historica”, w którym zamieszczono artykuł prof. Kołodzieja.

Kolejnym punktem uroczystości była laudacja prof. Krzysztofa Skupieńskiego na cześć Jubilata, prezentująca Jego dokonania naukowe, sylwetkę i profesjonalizm w pracy, jak również koleżeński styl bycia; mowa ta przeplatana była licznymi anegdotami. Następnie wystąpił redaktor Księgi Jubileuszowej prof. J. Łosowski, który omówił zawartość Księgi i przedstawił motywy jej powstania. Zaznaczyć należy też, że prof. Łosowski i Zakład Archiwistyki UMCS byli również organizatorami uroczystości. Momentem kulminacyjnym było uroczyste wręczenie Księgi samemu Jubilatowi. Wręczenia dokonali uczniowie prof. Kołodzieja - dr Tomasz Czarnota wraz z dr Małgorzatą Wnuk i mgr Elżbietą Markowską. Następnie głos zabrał Jubilat, który podziękował za uroczystość i laudacje. Oficjalną część uroczystości zakończyła dyskusja, w której udział brali prof. Janusz Szczepański, dr Tadeusz Krawczak, prof. Małgorzata Willaume oraz prof. Henryk Chałupczak z Wydziału Politologii UMCS. Także przyjaciele i koledzy Jubilata składali gratulację i dziękowali za udzieloną pomoc oraz spędzone razem lata pracy. Życzyli również dalszych sukcesów na polu naukowym. Wówczas dokonano wręczenia autorom egzemplarzy Księgi Jubileuszowej. Następnie prof. Skupieński zaprosił w imieniu Jubilata wszystkich zgromadzonych na poczęstunek w nowym budynku Wydziału Humanistycznego UMCS, podczas którego wznoszono toasty na cześć Jubilata oraz rozmawiano z Jubilatem o bieżących sprawach naukowych. Wówczas wyświetlano na rzutniku multimedialnym zdjęcia z oficjalnej części uroczystości. 
Jubilatowi życzymy dalszych imponujących osiągnięć naukowych i wszelkiej pomyślności. Ad multos annos!

Wojciech Luboch Instytut Historii UMCS w Lublinie

Dariusz Matelski

Poznań

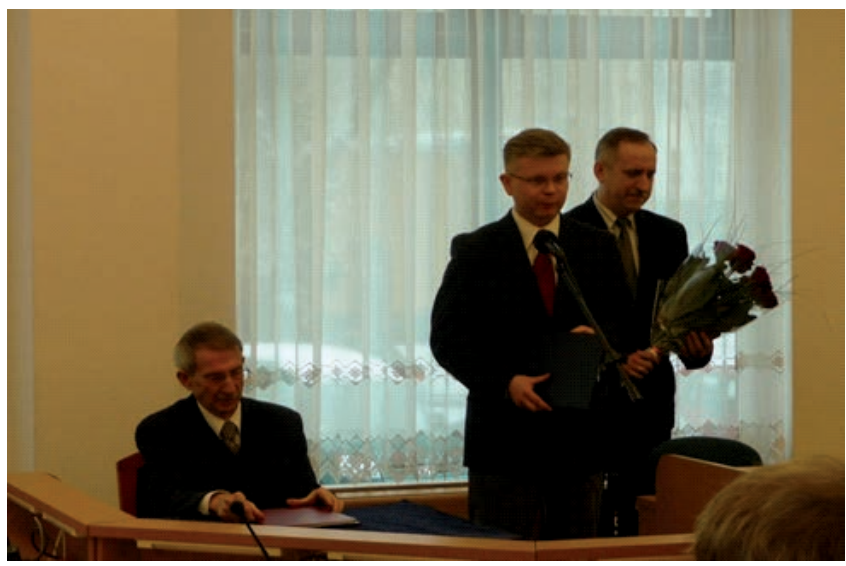

Lublin 21 grudnia 2011 r. Od lewej: prof. zw. dr hab. Edward Kołodziej, dyrektor Instytutu Historii UMCS prof. n. dr hab. Robert Litwiński oraz jego zastępca dr hab. Mariusz Korzeniowski (źródło: zbiory prof. Janusza Łosowskiego).

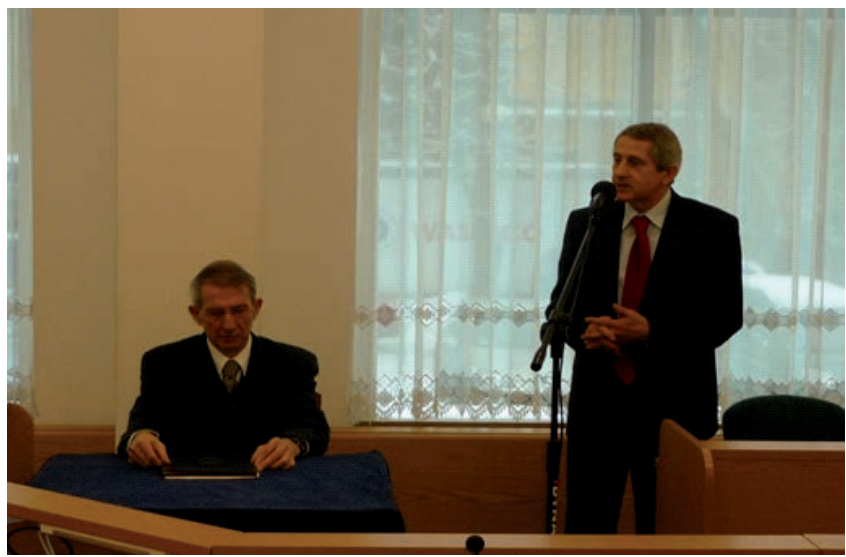

Lublin 21 grudnia 2011 r. Od lewej: prof. zw. dr hab. Edward Kołodziej i naczelny dyrektor Archiwów Państwowych prof. n. dr hab. Władysław Stępniak (źródło: zbiory prof. Janusza Łosowskiego). 